\title{
Die Nagmaal en broodgebrek
}

\author{
B J de Klerk \\ Departement Praktiese Teologie \\ Noordwes Universiteit (Potchefstroom Kampus)
}

\begin{abstract}
Holy Communion and want of bread

In Africa one out of three people suffers from undernourishment or malnutrition. In this respect the topical question whether Holy Communion and acts of charity to those who suffer from hunger can be linked. Jesus not only endows Holy Communion with a personal dimension of faith, but also foregrounds this aspect in the care for those who suffer from hunger. New Testament material reveals that in the congregation of Jerusalem partaking of Holy Communion developed into mutual diaconal care. It is thus for this reason inter alia that Paul warns against misusing Holy Communion. This kind of misuse was evident because the rich partook of Christ's meal of love without realising that they could only be part of this act of love by bestowing love themselves. In this article some practical guidelines to link the celebration of Holy Communion and the crisis of want of bread are discussed.
\end{abstract}

\section{INLEIDING}

Wydverspreide hongersnood kom wêreldwyd voor, maar is in Afrika, veral Sub-Sahara Afrika, gekonsentreerd. In hierdie gebied leef meer as 50\% van die bevolking onder die broodlyn (Gebre-Medhin 2005:27). Alreeds in 2000 is aangedui dat daar elke 3,6 sekondes iemand in die wêreld van honger sterf en drie-kwart daarvan is kinders onder die ouderdom van vyf jaar (Wepener \& Cilliers 2004:367). "The death of a starving child directly impacts the body of Christ - literary, not metaphorically" (Mitchell 2000:252). Die vraag is: Word die realiteit van honger in die liturgieë van al die kerke in die Suid-Afrikaanse samelewing genoegsaam aangespreek? Word byvoorbeeld honger in die Nagmaal, as element van die liturgie, gereflekteer en ook gekonfronteer? Moet die hartverskeurende situasie van honger gesinne nie ter sprake kom

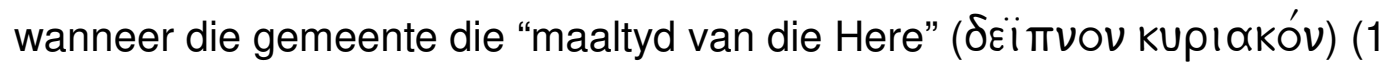
Kor 11:20) eet en drink nie? Christus het immers in Matteus 25 die liefde vir en verhoudings met hongeriges gekoppel aan 'n liefdesverhouding met Hom. 


\section{Die Nagmaal en broodgebrek}

Die Nagmaal word gebruik met brood en wyn en het dus regstreeks met voeding en die teenpool, honger, te doen.

Calvyn het drie werksaamhede van die Nagmaal aangedui: dit bevestig geloof, wek dankbaarheid en dit moedig gemeenskaplike liefde aan (Gerrish 1993:125; vgl Brienen 1987:214). Die vraag is of hierdie derde werksaamheid nie in die hedendaagse praktyk van kerke se Nagmaalsviering en die uitwerking van die Nagmaal op die daaglikse lewe verwaarloos word nie? Die probleemstelling in hierdie artikel kan dus só saamgevat word: Kan daar uit Skrifgegewens oor en die betekenis van die Nagmaal 'n verband tussen Nagmaal en liefdesdiens aan hongeriges getrek word? Indien wel, watter riglyne kan aan kerke gegee word om hierdie skynbaar verwaarloosde uitwerking van die Nagmaal met geesdrif aan te pak?

Om hierdie doel te bereik word die metode van Zerfass (1974:164-177) gevolg wat 'n basis-, meta- en praktykteorie behels. Die werkplan wat gevolg sal word, is om by wyse van empiriese ondersoek die huidige siening van die verband tussen Nagmaal en honger by 'n aantal predikante te probeer vasstel. Dit sal opgevolg word deur 'n poging om 'n beeld te verkry van die omvang van honger wêreldwyd. Daarna word beoog om ter saaklike Bybelse gegewens na te gaan: oor die konteks van die instelling van die Nagmaal en die verband tussen gewone maaltye en die Nagmaal in Handelinge 2 en 1 Korintiërs 11 . Ten besluite sal gepoog word om enkele praktiese riglyne aan te dui.

\section{EMPIRIESE ONDERSOEK}

In die empiriese ondersoek word 'n kwalitatiewe werkswyse gevolg. Daarom is onderhoude met respondente gevoer, wat kundiges op die gebied van nagmaalsgebruike is (Merriam 1998:48). Dit is ses predikante in dieselfde stad met opinies, ervarings en idees wat in die besonder verband hou met die mikpunte van die artikel: Drie van die predikante bedien lidmate by wie daar geen broodgebrek is nie (aangedui as PG1, PG2, PG3). Die ander drie word in hulle bedieningsveld dikwels gekonfronteer met lidmate wat ernstige hongersnood ervaar (aangedui as $\mathrm{PH} 1, \mathrm{PH} 2, \mathrm{PH} 3) .{ }^{1}$ Tydens onderhoudvoering in kwalitatiewe studies is oop-vrae en semi-gestruktureerde vraelyste gebruik. Dit dra by tot meer buigbare gesprekvoering (Leedy \& Ormrod 2001:159). Vooraf opgestelde onderwerpe, moontlike vrae en besprekingspunte wat gebruik is tydens onderhoudvoering, het veral gefokus op eksplorering van respondente se belewing van die verband tussen Nagmaal en honger. Analisering van data in 'n kwalitatiewe studie vereis dat groot

${ }^{1}$ Die volledige resultate van die onderhoude is by die outeur beskikbaar. 
hoeveelhede inligting deur induktiewe beredenering, uitsortering en kategorisering geleidelik tot kleiner stelle abstrakte en onderliggende temas verwerk word (Leedy \& Ormrod 2001:161). Eksterne beïnvloeding van data as gevolg van persoonlike aannames is sover moontlik vermy deur kritiese selfrefleksie oor persoonlike aannames, perspektiewe en teoretiese oriëntasie in ag te neem (Leedy \& Ormrod 2001:106; Merriam 1998:204, 211).

Op die vraag: "Wat is die verband tussen Nagmaal en honger", is die volgende antwoorde verkry: Ek het nog nooit daaroor gedink nie, maar die "wag vir mekaar" in 1 Korintiërs dui daarop dat daar wel 'n Bybelse verband gelê kan word (PG1). Nagmaal dui op die eenheid waarin almal verantwoordelik is vir almal (PG2). Die meeste mense vergeestelik bloot die Nagmaal en daar is baie min mense wat met die Nagmaal aan meer as geestelike voedsel dink. Die Nagmaalsformulier maak ook nie melding van die verband tussen fisiese honger en die gebruik van die Nagmaal nie (PG3). Die konsep van deel met mekaar in die Afrika-kultuur vorm 'n verband tussen die Nagmaal en honger. Paulus gee die indruk dat daar 'n gemeenskapsmaaltyd in Korinte was wat hand aan hand met die Nagmaal gepaard gegaan het (PH1, PH3). In Handelinge 2:42-46 word die Nagmaal en die uitdeel van kos met mekaar verbind ( $\mathrm{PH} 2)$.

Dit is uit die antwoorde duidelik dat al die respondente vermoed dat daar wel prinsipieël ' $n$ verband bestaan. Die volgende aspek in die gesprek het gehandel oor implementering van die beginsel. Daar is gemeentes wat ná die Nagmaal soms saam eet, maar daar word nie 'n verband gelê tussen die Nagmaal en sulke gemeente-etes nie (PG1, PG2, PG3). In slegs een geval (PG1) word die voedsel wat oorbly aan organisasies verskaf wat dit na eie goeddunke hanteer, maar dit word nie regstreeks aan honger mense gegee nie. Die Nagmaalsviering dra tans weinig of geensins by om lidmate wat daaraan deelneem sensitief te maak vir mense wat lewe in 'n konteks van honger nie (PG3, PH1, PH3). Al die respondente dui aan dat daar deeglike toerusting oor die roeping wat spruit uit die Nagmaalsviering om by honger mense betrokke te raak, moet kom (PG1-3 en PH1-3). Oor hoe die toerusting moet plaasvind is daar nie duidelikheid nie (PG2, PH2, PH3). By nie een van die kerke waar hierdie predikante dien, is daar gesamentlike Nagmaalsvierings met ander kerke nie, en beslis nie tussen kerke waarin daar nie en kerke waarin daar wel lidmate is wat honger ervaar nie.

Uit hierdie kort oorsig oor die resultate van onderhoude met die ses predikante, wat 'n verantwoordbare snit uit die kerklike wêreld kan aandui, blyk dit dat verdere navorsing nie bloot van akademiese waarde kan wees nie, maar ook die kerklike praktyk kan dien. Die beeld wat verkry word uit statistiek rondom hongersnood, asook die getuienis van mense wat ly as gevolg van 


\section{Die Nagmaal en broodgebrek}

voedseltekorte, kan bydrae tot groter kerklike betrokkenheid by honger, en word nou verder ondersoek.

\section{3. 'N BEELD VAN DIE NOOD WAT HONGER MEEBRING}

Huidiglik ly een uit elke drie inwoners van Afrika aan ondervoeding of wanvoeding en die helfte van Afrika se 700 miljoen inwoners leef met minder as $\$ 1$ per dag, die meeste ( $80 \%$ ) met minder as $\$ 2$ 'n dag. Meer as 10 miljoen mense in Lesotho, Malawi, Mozambique, Swaziland, Zambië en Zimbabwe benodig humanitêre hulp en die groeiende vlakke van honger word vererger deur die effek van MIV/Vigs, as die hoofoorsaak van chroniese kwesbaarheid in hierdie streek (Anon 2005:1). Dit lei tot groei in voedselpryse, wat veral die armer huishoudings swaar tref (Anon 2005:2). Die las van versorging op MIVgeaffekteerde en nie-MIV-geaffekteerde huishoudings lei verder tot verminderde boerdery aktiwiteite (Anon 2003:2). Die sensitiwiteit van landelike gemeenskappe vir eksterne skokke soos droogtes en siektes wat verband hou met honger, het verhoog (De Waal \& Whiteside 2003:1235). Botswana byvoorbeeld worstel sedert Januarie 2006 met 'n diarree epidemie wat die lewens van meer as 500 kinders geëis het. Dr Dorothy Ochola, Projekbestuurder by UNICEF stel dit so: "Severe, acute malnutrition, secondary to diarrhoea, is contributing to the high fatality rate" (Leshomo 2006).

Die moontlikheid om anti-retrovirale medisyne te verkry het in Kenia verbeter en daar is die afgelope twee jaar ses keer meer mense wat hierdie soort behandeling ontvang. Ernstige droogte in Kenia en die Horing van Afrika het meegebring dat pasiënte wat anti-retrovirale medikasie ontvang, maar nie genoeg het om te eet nie, nie vir die uitwerking van hulle medisyne weerstand kan bied nie. Daarom het hulle die behandeling gestaak. Een van hierdie pasiënte se kommentaar was:

If you don't have any breakfast you can't take these drugs because when you swallow them you feel in your stomach pain ... and awful dizziness. If somebody has 50 bob [shillings] ( $\$ 0.75 ; £ 0.40)$ he or she would rather buy food to eat than take pills. They know HIV will not kill them immediately, but famine might kill you in one week.

(Anon 2005:3)

Meer as $16 \%$ van kinders onder vyf in die ontwikkelende wêreld lei aan ernstige wanvoeding en baie van hulle is swak en kwesbaar vir siektes. Die meeste van hulle weeg baie min by geboorte en die gevolge daarvan vir hulle 
latere lewe is ernstig: sommige sal leerprobleme ondervind as hulle ooit skool kan bywoon. Hulle sal steeds die armstes van die armes bly (UNICEF 2005:20).

The hungry suffer from inadequate kilojoule intake (below $80 \%$ of the generally accepted poverty threshold), insufficient health care, lack of sufficient assets, shortages of training and skills. They spend the major part of their income $(70-80 \%)$ on food, mostly inexpensive starchy staple foods.

(Du Toit 1997:292)

Die mikpunt van 'n VN konferensie in 1990 om die aantal persone wat in ekstreme honger-toestande leef met die helfte in 2015 te verminder, sal faal. Volgens Havnevik (2005:110) sal die doelwit van die FAO Food Summet van 1996 om die aantal persone wat voedsel tekorte beleef met die helfte teen 2015 te verminder, ook nie bereik word nie.

Die kerk moet só op die omvattende probleem van honger fokus dat lidmate sensitief bly vir die individu, 'n persoon met 'n naam, met 'n eie menswaardigheidsgevoel en met ' $n$ mens wat ' $n$ besondere ervaring van honger het. Statistieke kan oorweldigend wees, maar dit kan só neerdrukkend word dat gelowiges onmagtig voel om iets daaraan te doen (Du Toit 1997:291). Deur betrokke te wees by iemand in sulke unieke omstandighede en met wie persoonlike bande ontwikkel word, kan meebring dat nuwe moontlikhede ontdek word. Daarom moet verder vasgestel of daar afleidings gemaak kan word oor die verband tussen honger (of die teenpool, eet en drink) en die instelling van die Nagmaal deur Jesus sowel as die gebruike in die Jerusalemse gemeente.

\section{DIE INSTELLING VAN DIE NAGMAAL EN GEBRUIKE IN DIE JERUSALEMSE GEMEENTE}

Jesus stel die Nagmaal in tydens die viering van die Pasga. Matteus 26:26-28 begin so: "Terwyl hulle eet het Jesus die brood geneem ... " Die Nagmaal sluit aan by en toon ooreenkomste met die Pasga: "Both are religious feasts in which participation takes the form of eating and drinking" (Phillips 2003:195). Terwyl hulle eet, breek Hy die brood en wanneer Jesus die brood uitdeel praat Hy onverwags van sy liggaam en 'n uur-en-half later (na die eet van die paaslam) van sy bloed. Hy is die ware Pasga-offer. In die eet en drink van die tafelgenote gee Christus aan hulle deel aan die versoenende krag van sy 


\section{Die Nagmaal en broodgebrek}

dood en hierdie deelname neem die vorm aan van eet en drink (Phillips 2003:194). Jesus maak daarvan 'n feestelike maaltyd, soos wat die Pasga was. Die maaltyd is gemeenskap met God en mekaar, die vreugde van verbondsvernuwing en verwagting van die vreugdemaal in die Koninkryk. Die vreugde neem konkrete gestalte aan in die sorg vir die armes - soos by die feesmaaltyd in die ou verbond (Deut 16:14; Joh 13:29 se laaste deel). Die onderlinge versorging kom in hierdie klimaat na vore.

Die verskillende aspekte van die Nagmaalsviering het ook betrekking op deel kry en uitdeel. Die "doen tot my gedagtenis" (anamnesis) is dinamies van aard. As God nie meer aan die sonde dink nie, dan bestaan dit nie meer nie. So is dit ook met die gedenk aan sy offer: dié wat eet en drink kry deel aan die vrug daarvan (Boendemaker 1998:227). Die hartverheffing by die viering van die Nagmaal is van kardinale belang en daarom is die eet van die brood en die drink van die wyn 'n diep en ondeurgrondelike gemeenskap met die lewende Christus. Calvyn kon die geheim van die Nagmaal nie met sy verstand omvat nie en daarom skryf hy in Boek IV.xvii.32: "As enige iemand my vra hoe dit plaasvind sal ek nie skaam wees om te bely dat dit 'n geheim is ver bo my verstand en bo woorde om dit te verklaar. Ek kan dit eerder ervaar as om dit te verstaan. Daarom omhels ek die waarheid van God en vind daarin my rus." Die gemeenskapsmaaltyd sluit in gemeenskap met Christus en met mekaar. Die breek van die brood deur Jesus by die instelling van die Nagmaal, gee 'n nuwe betekenis aan hierdie handeling. Soos Jeremia die pottepakker se pot moes breek as simbool van die val van Jerusalem, so is die breek van die brood simbolies van die breek van sy liggaam. Hy deel dit uit sodat hulle deel kan hê aan sy dood. "Eating and drinking in the church is a ritual memory of the death of Christ and reminds us of the story of which we are a new chapter" (Leithart 2000:29).

Dat in Handelinge 2 in dieselfde verband dieselfde uitdrukking "breek van die brood" eers met betrekking tot die Nagmaal en direk daarna met betrekking tot die "gewone" maaltye gebruik word, kan net op een manier verklaar word. Die één uitdrukking "breek van die brood" kan sowel op die vier van die Nagmaal as op die hou van 'n maaltyd betrek word, omdat die twee toe nog onlosmaaklik aan mekaar verbonde was. "De viering van het avondmaal vond nog plaats in het kader van een gemeenschappelijk gebruikte maaltijd" (Versteeg 1980:10). Ook in Handelinge 20 word die viering van die Nagmaal ( $\vee 7$ ) en die gewone maaltyd ( $v 11$ ) albei met "breek van die brood" aangedui omdat hulle toe nog inmekaar verweef was. Die sosiale gemeenskap in die tyd van Jesus se aardse lewe kon ook van rykes verwag om 'n gemeenskaplike maaltyd te reël en dan moes die ete mense van alles stande insluit. Die rykes moes die minderbevoorregtes van die samelewing 
uitnooi sonder om 'n soortgelyke optrede terug te verwag. In Handelinge 6:2 was die tafel nie 'n sakramentele tafel nie, maar dien dit primêr vir die daaglikse versorging (Hand 6:1). Dit was 'n tafel vir die daaglikse brood. Liefdesmaal en Nagmaal val saam: die armes word gevoed aan die tafel wat die rykes gedek het (Trimp 1989:122). 'n Klein deeltjie van dit wat mense bring vir versorging word vir die gedagtenis aan Christus se dood benut en die oorgrote deel was bestem vir die behoeftige broers en susters. Die diakonale liefdesdiens word vanaf die tafel moontlik gemaak.

In die Jerusalemgemeente is omvattende hulp tydens saameet geleenthede aan behoefige gelowiges verleen (Vermaak 2000:48). Die gemeenskaplike maaltyd het onderlinge meelewing versterk deurdat ryk en arm saamgeëet het. Omdat die Here hulle seën is hulle ook 'n seën vir mekaar. Vermaak (2000:55) kom tot die konklusie in sy studie oor die gemeenskaplike maaltyd in Handelinge 2:42 dat die "breek van die brood" (Tn̂

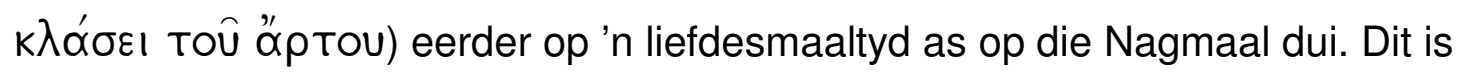
egter wel so dat die Nagmaal tydens die liefdesmaaltye gevier is en die Nagmaal is nie van die liefdesmaaltye losgemaak nie, maar het daaruit voortgevloei.

Die oorsprong van die insameling van die gawes in die erediens lê in die deel van die gawes (natuurlike voedselgawes) by die liefdesmaaltye van die eerste gemeente. So vier die gemeente gemeenskap met die Here en met mekaar. Wat van die kos oorbly, gaan na die armes, siekes en gevangenes. Nagmaal loop oor in diakonaat; erediens in diensbetoon. In die antwoord op God se barmhartigheid (ontferming) gaan dit om die offer van die self (Rom 12:1; Oskamp 1998:224). "De eucharistie als maaltijd roept heel de werklijkheid op van het materiële, het lichamelijke, het economische en van de sociale gewoonten en gebruiken die onvermijdelijke in alle culturen het eten en drinken begeleiden" (Lukken 1996:25).

Dit is dus duidelik dat vanaf die instelling en die viering van die Nagmaal in die eerste (Jerusalemse) gemeente daar 'n noue verband tussen die Nagmaal en 'n gewone ete was. Daarom het daar uit die viering van die Nagmaal tydens die gemeenskaplike maaltye dikwels versorging van hongeriges en armes voortgespruit. In hierdie verband kom die verkeerde praktyk wat Paulus in 1 Korintiërs 11:17-34 aanspreek ter sprake. Watter afleidings kan uit hierdie perikoop vir die verband tussen Nagmaal en honger gemaak word? 


\section{Die Nagmaal en broodgebrek}

\section{DIE PERSPEKTIEF VAN 1 KORINTIËRS 11}

In 1 Korintiërs 11:17-34 spreek Paulus sy kommer uit oor die viering van die Nagmaal in die gemeente van Korinte en die verdeeldheid wat dit veroorsaak nadat berigte hom hieroor bereik het (v 11:18; Leuschner 2005:135). Vyf keer

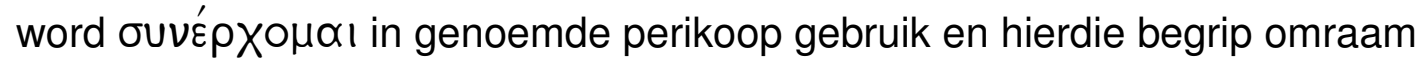
hierdie gedeelte ( $\vee 17$ en $\vee 34$ ). Wat hier ter sprake is is nie blote sosiale etes nie, maar bepaalde gemeentelike samekomste waartydens daar saam geëet is. In die Vroeë Kerk het die gemeentes in die huise van meer gegoede gashere bymekaar gekom vir die gemeenskaplike maaltye (Quast 1994:72). Elke persoon het voedsel en drank saamgebring om dit met mekaar te deel. Gedurende hierdie "liefdesmaaltye" het die gelowiges die Nagmaal gevier met simboliese woorde en dade.

Die maaltyd het vir die bevoorregtes in die eetkamer (triclinium) begin voordat die res van die gemeente teenwoordig was.

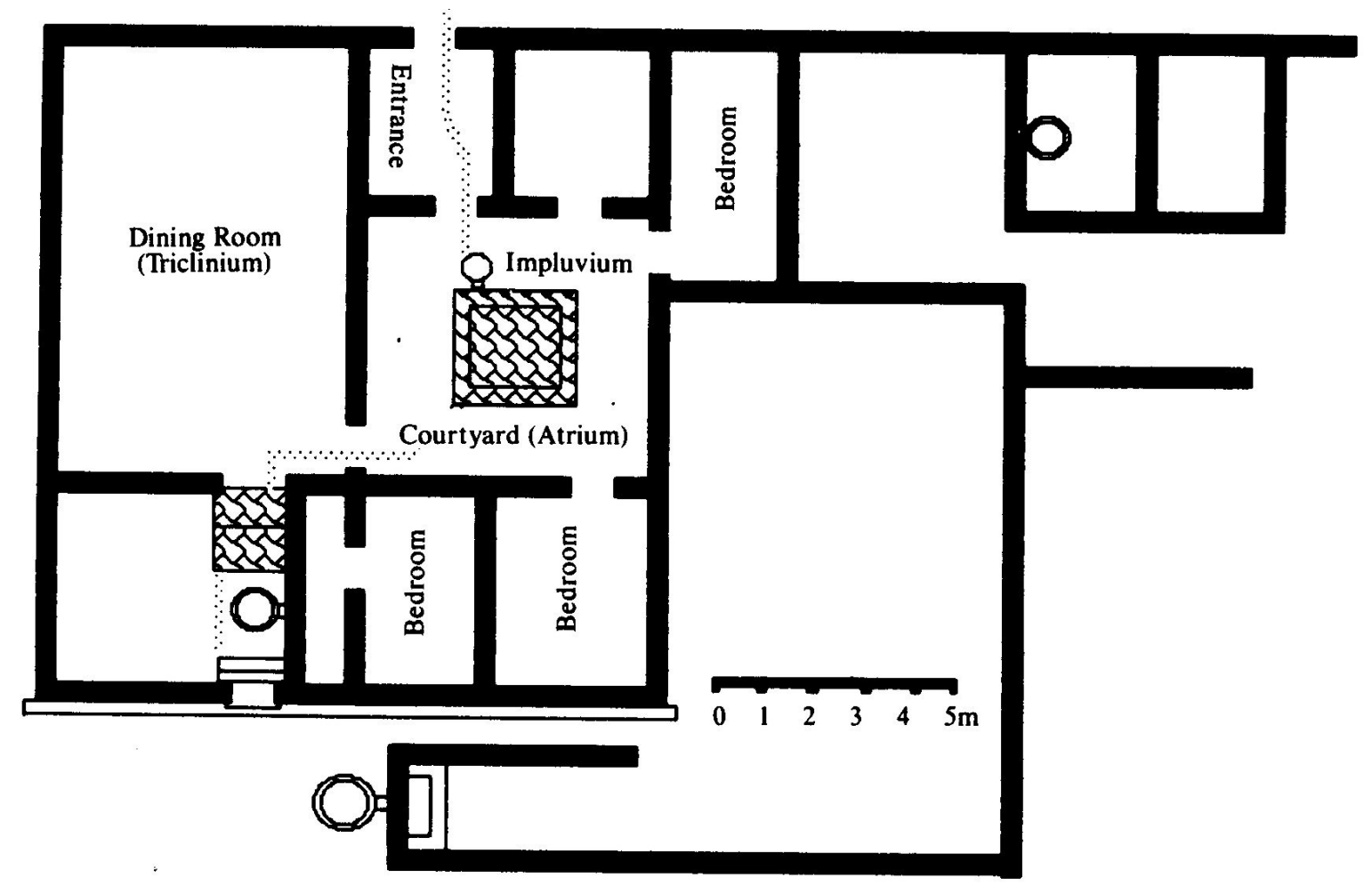

Huis in Korinte

(Quast 1994:73) 
In die huis was daar 'n kleiner vertrek (triclinium) in die binneste deel en verder was daar as intreevertrek die atrium. Die gasheer het dus sy beste vriende tussen die gelowiges genooi om in die triclinium saam te kom, mense van sy sosiale klas. Die res moes dat hulle plekke inneem in die atrium, waar die omstandighede nie so gunstig was nie (Blue 1991:229). Witherington (1995:29) argumenteer dat die gashere (welgestelde burgers wat hulle eie huise gehad het) dalk net die normale gebruike van daardie tyd gevolg het deur ryk handelaars in die gemeente in een vertrek met een tipe kos te bedien en die armes en slawe iewers anders met die oorblyfsels. Omdat die eetkamer (triclinium) van die gemiddelde huis van daardie tyd net plek vir 9 tot 20 mense gehad het, het dit daartoe gelei dat daar 'n oorvloei na die binneplein (atrium) was. Die probleem was dat die huiseienaar en gasheer die verdeling op grond van sosiale status gedoen het en dan verskillende kos op verskillende tye aan die verskillende lokale bedien het. Die sosiale verskille in die gemeente is sodoende oorbeklemtoon en vererger. Die Nagmaal is egter 'n fees vir gelowiges en hulle word nie aan stand, status, geslag, ras of leeftyd geklassifiseer nie. By die Nagmaal is daar nie ereplekke nie, want almal se status is dat hulle kinders van God is (Vos \& Pieterse 1997:175).

Baie duidelik en eksplisiet koppel Paulus dus Nagmaal en gewone maaltyd aan mekaar. Hy waarsku teen die misbruik van die Nagmaal wat in die gemeente voorgekom het. Die misbruik van die Nagmaal hang nou saam met die misbruik van die gewone maaltyd waarin die viering van die Nagmaal opgeneem was. Die maaltyd loop uit op die viering van die Nagmaal, of wat meer waarskynlik is, tydens die maaltyd vind die Nagmaal plaas. Hierdie samehang van die twee word in 1 Korintiërs 11:20 aangedui as die "maaltyd van die Here". Dat hierdie maaltyd van die Here meer omvat het as net die Nagmaal word uit die volgende twee verse duidelik. Paulus teken in hierdie verse die situasie in die gemeente van Korinte: Die rykes eet en drink dit wat te eet en te drink is vir die gemeenskaplike maaltyd en wag nie vir die armes nie. Wanneer die gemeente as geheel dan bymekaar was, was die situasie so dat sommige honger en ander dronk was (v 21). Moontlik bedoel Paulus nie letterlike dronkenskap nie, maar gebruik die uitdrukking om die skerpste teenstelling te kan maak, of moontlik was hulle tog werklik dronk (Versteeg 1980:11). Voor die eintlike samekoms begin het die rykes alles verorber. Daarom vra Paulus in vers 22: "Het julle dan nie huise om daar te eet en te drink nie? Of verag julle die gemeente van God en beskaam julle hulle wat nie het nie?"

In plaas daarvan om vir die minder bevoorregte naaste ruimte te maak aan die gemeenskaplike maaltyd of ' $n$ bietjie te wag tot almal teenwoordig is (vgl v 11:33), is daar groepies wat hulle afsonder en haastig hulle eie maaltyd 


\section{Die Nagmaal en broodgebrek}

eet ( $v 11: 21)$. Met meer vrye tyd tot hulle beskikking het die rykes vroeër bymekaar gekom as wat die slawe en vrygelatenes, wat langer ure gewerk het, dit kon doen (Quast 1994:72). Hulle samekomste het daarom meer skade as goed gedoen.

"For Paul meal and celebration still belong so closely together that he can maintain that the bad state of affairs in the common meal makes the entire Lord's Supper illusory" (Blue 1991:229). Hier word teenstellings soos

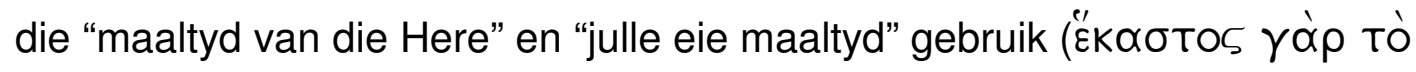

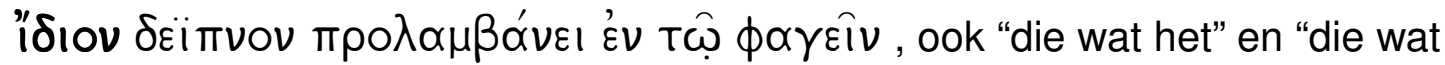
nie het nie". Sekere dinge is geoorloof in jou eie huis, maar nie wanneer die gemeente in 'n huis saamkom nie. Sommige het huise, ander het niks. Sommige gelowiges het genoeg voedsel en drank, maar ander beleef 'n ernstige tekort aan genoeg en voedsame kos. Gemeenskap is vir Paulus só belangrik dat dit vir hom die hoofsaak is waarom dit in 1 Korintiërs 11 gaan. Die feesviering moet die gemeenskaplike sorg vir mekaar uitdruk. Hulle moet daarom vir mekaar wag. Hulle moenie eet soos in 'n kafeteria waar elkeen die kos eet wat hy/sy gekies het nie. Elkeen eet dan wat hy/sy kan bekostig. Maar dié wat baie het, moet dit deel met dié wat nie genoeg kos het nie. Dit 'n verbondsmaaltyd waar almal gemeenskap met God het en met almal binne die verbond (Old 2002:116).

Paulus beklemtoon baie duidelik in 1 Korintiërs 11:17-34 dat daar in die Nagmaal nie van gemeenskap met Christus sprake kan wees waar daar nie ook gemeenskap met mekaar is nie. Ondanks hulle liefdelose miskenning van die armes meen die gemeente tog dat hulle die Nagmaal kan vier. Dit noem Paulus "onwaardige eet en drink" (vv 27 \& 29; Versteeg 1980:56). Paulus bedoel met die eet en drink "op 'n onwaardige wyse", eet en drink op 'n liefdelose wyse. Die rykes in die gemeente gedra hulle teenoor die armes op 'n wyse wat nie by die viering van die Nagmaal pas nie. Hulle wil in die Nagmaal die maaltyd van die liefde van Christus geniet sonder dat hulle besef dat hulle dit alleen kan doen deur ook self liefde te bewys. Die feit dat hulle nie wag vir die armes nie wys dat hulle nie dink aan die armes nie. Hulle wil die gemeenskap met Christus in die Nagmaal ontvang, maar vir die gemeenskap met mekaar in die Nagmaal het hulle nie enige belangstelling nie. Elke liefdelose Nagmaalsviering wat spruit uit 'n egoïstiese en individualistiese Nagmaalsviering word deur Paulus in 1 Korintiërs 11:27 en 29 aan die kaak gestel as "onwaardige eet en drink" (Versteeg 1980:57).

Hierdie vorm van Nagmaalsviering wek God se toorn. Wie in die Nagmaal wel die gemeenskap met Christus, maar nie gemeenskap met ander gelowiges wil soek nie, maak nie net 'n betreurenswaardige fout nie, maar laai 'n verskriklike skuld op hulle as gemeenskap. "This failure of the rich to 
recognize the body of the Lord in their poorer brethren also resulted in divine judgement: Many of them were sick, and a number had even died" (1 Cor 11:27-32) (Atkerson 2005:2). Die gemeente van Korinte moet hulleself beproef om nie op ' $n$ liefdelose wyse die Nagmaal te vier nie ( $v 28)$. Dit gaan nie in die selfondersoek óf die Nagmaal gevier óf nie gevier moet word nie, maar oor hoe en met watter gesindheid en voorneme die Nagmaal gevier moet word (Versteeg 1980:57). Die regte wyse van selfondersoek word hier aangedui: is daar nie dalk ' $n$ egoïstiese, liefdelose houding by Nagmaalgangers aanwesig wanneer gelowiges nie die nood van mede-gelowiges, wat broodgebrek ly, raaksien of dit ignoreer nie?

Die liefdesmaaltyd moet die honger van die armes stil en daarom kan die rykes nie bloot hulleself, hulle eie liggame voed nie, maar moet hulle die liggaam van Christus voed. "The Corinthian controversy over the Lord's Supper (11:17-34) split the church along status lines. Paul speaks of those who 'have not' as oppose to those who 'have' things like houses in which to eat and drink their fill" (Martin 1995:73). Die wat het, het beheer oor hulle tyd en kon by die samekomste aankom net wanneer hulle wil. Die ander was arbeiders, slawe wat nie beheer oor hulle tyd gehad het nie. As die aard van die liefdesmaaltyd daarmee verlore gaan, kan dit net sowel gelaat word en kan almal liewer tuis eet, want so vertoon die rykes veragting vir die kerk van die Here. Hulle egoïstiese gedrag wys dat hulle nie 'n hart en 'n hand vir God se gemeente het nie. "Paul's reverence to the 'body' can refer either to the eucharistic loaf, the body of Jesus hanging on the cross, or the fellowship of believers. To take the Lord's supper without discerning the body is to observe it with no consideration for the church, the body of Christ" (cf 1 Cor 10:17; 12:12-27; Quast 1994:76). Hulle skend die eenheid en dink net aan hulleself, vergeet die broederliefde en veroorsaak $\sigma x_{i} \sigma \mu \alpha \tau \alpha$. "These shameful class divisions cut at the heart of the unity the Lord's Supper is designed to achieve" (Atkerson 2005:2). Die gemeente moet daarom selfondersoek instel om hierdie kwaad so te bestry. In verse 33 en 34 leer hy hulle wat om te doen, naamlik om vir mekaar te wag en as die rykes dan dalk sou honger word, moet hulle vooraf tuis iets eet. Anders verval hulle in die sonde van geestelike hoogmoed, en dit is die Korintiese gemeente se wortelsonde.

Uit die Nuwe Testament en die vroegste geskrifte kan afgelei word dat die Christene allerlei gawes in natura na die erediens gebring het. Dit is aanvanklik gebruik vir die liefdesmaaltye, maar ook vir die sorg van behoeftiges. Daar kan aangeneem word dat hierdie gawes ook gebruik is vir die viering van die Nagmaal. Volgens Oskamp (1987:27) is dit wat oorgebly het onder die behoeftiges versprei. Vanaf die Derde eeu is die bring van die gawes duidelik ingesluit by die viering van die Nagmaal. Sedert die Elfde eeu 


\section{Die Nagmaal en broodgebrek}

verval die bring van gawes in natura en word dit vervang met offers in geld (Wepener \& Cilliers 2004:368). Om net 'n maaltyd te hê en dit Nagmaal te noem is nie genoeg nie - gelowiges moet weet wat hulle doen en hoekom hulle dit doen $(11: 28)$ en dit gevolglik reg doen. Hierdie soort maaltyd, die liefdesmaaltyd, was 'n soort van armversorging. Deurdat die rykes meer bring as die armes en almal tog saam eet, ontstaan 'n soort van gelykheid (2 Kor

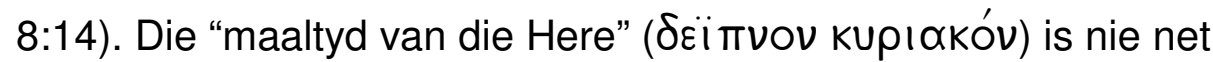
liefdesmaaltyd nie, want die Nagmaal vorm deel daarvan. Dan word die

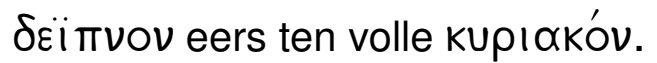

So dikwels as julle die Nagmaal vier "verkondig julle die dood van die Here". Die handeling van die Nagmaal as sodanig is nog geen verkondiging van die dood van die Here nie, maar vra wel om verkondiging. Die eet van die brood en die drink van die wyn behoort by die gelowiges te lei tot belydenis aangaande die dood en opstanding van Christus. Hierdie belydenis is immers 'n belangrike element van die Nagmaalsviering. Die Nagmaalsviering is nie volledig sonder hierdie verkondiging nie (Versteeg 1980:62). Hierdie verkondiging moet in woorde, maar in die konteks van die perikoop, ook met liefdesdade gedoen word.

\section{PRAKTYKTEORIE EN PRAKTIESE RIGLYNE}

\subsection{Praktykteoretiese aspekte}

Uit bogenoemde gegewens kan die Nagmaal beskryf word as:

- 'n gemeenskapsmaal waar die gelowige gemeenskap met God en met mekaar beleef;

- 'n herinneringsmaal waardeur die gelowige herinner word aan Jesus Christus se dood en opstanding;

- 'n verkondigingsmaal wat Jesus Christus as Here verkondig aan almal teenwoordig;

- 'n verbondsmaal waardeur die verbond tussen God en die gelowige bevestig word

- en 'n verbintenismaal waardeur die gelowige hom of haar tot gemeenskap met God en met mekaar verbind. Hierdie laaste aspek, naamlik verbintenis tot liefdesdiens aan die naaste, kom in die praktykteoretiese bespreking aan die orde. 
In die hart van die Christelike erediens klop die nood van die wêreld en kan dit verwoord en in praktyk gebring word deur erediensdeelnemers. Dit geskied onder andere in die lofprysing, danksegging, skuldbelydenis en voorbidding van die gemeente, asook in die aanhoor en toepas van die Woord. Dit geskied ook deur die gebruik van die sakramente en die liefdegawe wat daaraan gekoppel is (Smit 2004:352), want in die erediens word die kerk se liefdesdiens in die wêreld weerspieël (De Klerk 1987:3).

Once sacrament theology has been genuinely situated in ecclesiology, it becomes apparent that the sacraments are inseparable from the mission of the church and the church's relationship to the world in such a way that we can consider sacramental theology as an aspect and a way of examining the church's relationship to culture.

(Leithart 2000:164)

Die Reformasie herstel die Nagmaal weer as maaltyd van gedagtenis aan en gemeenskap met Christus. God se gawe aan ons staan sentraal. Christus is tegelyk Gasheer en Gawe van die Nagmaal. Die Nagmaal breek die deure na die alledaagse lewe toe oop en dien as middel van God se genade tot heiliging van die lewe voor God (Trimp 1989:128). Die Nagmaal bring tot danksegging, 'n offer van dank en dit sluit nie net die loflied in nie, maar ook mededeelsaamheid aan ander (Heb 13:15,16). Calvyn het Nagmaal en die gee van liefdegawes intiem aan mekaar verbind, soos sy stelling aandui: "Dit moet so geskied dat geen vergadering van die kerk plaasvind sonder die Woord, gebede, deelname aan die Nagmaal en aalmoese nie" (Calvyn 1991:1747).

In die viering van die Nagmaal smaak die gelowiges reeds die gawes van die komende ryk, roep saam Maranata, Here kom!, en gaan dan uit na diegene met nood, veral honger, om die beloftes en goedheid van Christus met hulle te deel. In die geskiedenis was die weeklikse Nagmaalsviering daarom die oomblik waartydens daar konkreet vir die behoeftes van die wêreld gebid is, en waarvandaan die diakens as dienaars uitgestuur is met konkrete liefdesgawes vir diegene in nood (Smit 2004:353).

Die onderlinge verbondheid van die gelowiges is ook ' $n$ voortdurende uitdaging by die soeke na die regte verhouding in die sosiale, ekonomiese en politieke lewe: die eucharistie neem die gelowige op in die sentrale gebeure van die wêreldgeskiedenis (Uytenbogaardt 2002:169). Die Nagmaal beklemtoon wel die gemeenskap met mekaar: Net soos uit baie graankorrels 


\section{Die Nagmaal en broodgebrek}

een brood en uit baie druiwekorrels een wyn voortkom, so moet almal wat in Christus ingelyf is een liefdesgemeenskap wees. Maar daar is ook 'n nou verband tussen die Nagmaal en eet en die uitdeel van dit wat gelowiges het. Behalwe die brood en wyn aan die tafel, is daar ook mense wat ' $n$ handeling verrig. Hulle kyk nie net na die elemente en laat dit verbygaan nie. Hulle gee dit aan, deel dit, eet dit en drink dit. Dit gaan dus ook oor die verhouding tussen die gebruikers en oor die geniet van die skepping van God, wat ook 'n oog het vir skepsele in nood (Leithart 2000:160). Nagmaal kan dus nie beperk word tot tekens en seëls nie, maar die handeling daarin moet ook in aanmerking geneem word. 'Defining sacraments as 'signs' often carries intellectual freight, so that the sacraments come to be understood as material for contemplation or visual aid to teaching" (Leithart 2000:163).

\subsection{Enkele praktiese riglyne}

\subsubsection{Verkondig die dood van Christus ook deur liefdesdade - gee toerusting}

Deur die eet van die brood en die drink van die wyn verkondig die gemeente die dood van die Here totdat Hy kom (1 Kor 11:26). Die verkondiging is nie net 'n verbale daad nie, maar 'n lewensdaad (Vos \& Pieterse 1997:179). As "Gäste des Gekreuzigten" het die gelowiges ook 'n wêreldverantwoordelikheid (Gerhard 1993:185). Hierdie verantwoordelikheid word nagekom deur ander van die heil te vertel, meer nog as die dade, ook die liefdesdade, van gelowiges dit uitstraal. Jesus Christus is die brood van die lewe en wie daardie brood in die Nagmaal geniet, word al meer wat hulle reeds in Christus is, naamlik lewende lede van sy liggaam. So kan hulle weer brood word in hulle verhouding met ander gelowiges en buitestanders deur die opofferende liefde van Christus wat hulle in die Nagmaal ingeneem het aan hulle deur te gee. Wie die brood neem en eet, moet ook aan ander brood gee. Dit is die etiese aspek van die Nagmaal wat die gelowiges oproep om na mekaar en na ander om te sien. Die etiese aspek van die Nagmaal open deure en vensters na die wêreld (Vos \& Pieterse 1997:178). Die Nagmaal stuur gelowiges die wêreld in om God se heil geestelik en liggaamlik aan almal in die wêreld te gaan bemiddel. Dit is juis hierdie missionêre en diakonale aard van die liturgie wat gelowiges van elke vorm van introversie behoed (Scheer 1996:147).

In die prediking en ander onderrig moet hierdie opdrag duidelik uitgespel word. Lidmate behoort van die Nagmaalsviering weg te gaan met die duidelike insig dat die viering hulle tot liefdesdiens in die algemeen, en tot die aanspreek van die hongervraagstuk in die besonder, opwek. Gemeentes moet deur toerusting gelei word tot nuwe insigte hieroor, ook om weerstande wat daar mag wees, te kan oorkom. 


\subsubsection{Oorweeg gesamentlike nagmaalsviering}

Taljaard (2004:373-379) beskou die Nagmaal as 'n middelruimte tussen ryk en arm gelowiges. Dit bied die geleentheid vir kommunikasie, konfrontasie, begrip vir mekaar en genesing. Die Nagmaal is 'n ruimte waar elkeen sy/haar identiteit kan herinterpreteer en waar die identiteit van ander nuut gesien en waardeer kan word. Hierdie "middelruimte" bind ryk en arm, wie het en wie honger is in Christus aan mekaar en so kan gelowiges mekaar as gelykes ontmoet. Dit word moontlik gemaak deur Christus se teenwoordigheid (as Gasheer en as Gawe) en so word gelowiges uit verskillende lewensomstandighede saamgebind (as huisgesin) in hierdie middelruimte van die Nagmaal. In hierdie ruimte kan gelowiges die eenheid ervaar om één liggaam van Christus te wees en om deur een brood gevoed te word. Die gesamentlike Nagmaalsviering bied die ruimte om pyn te deel en om mekaar te vergewe. Dit is die ruimte waar die onreg en pyn en verdeeltheid van die verlede die toekoms van hoop ontmoet. Dit is die ruimte waar deelnemers aan die Nagmaal brood vir die wêreld word en vanwaar ander uitgenooi word om gemeenskap met Christus en sy liggaam, die kerk te hê (Taljaard 2004:377).

Gemeentes wat bestaan uit persone wat nooit voedseltekorte het nie en gemeentes waarin daar lidmate is wat broodgebrek ervaar moet moeite doen om soms (een keer per jaar?) gesamentlik die fees van die dood en opstanding van Christus in die Nagmaal te vier.

\subsubsection{Gemeente-etes kan 'n moontlike rol speel}

Vanuit die perspektief dat gemeentelike etes en die Nagmaal uit die staanspoor 'n noue verband vertoon het, kan die Nagmaal soms in die raamwerk van gemeente-etes gevier word. Sommige individuele gemeentes het reeds iets van ' $n$ tradisie om soms na 'n Nagmaalsviering saam te eet. By sulke etes bring elkeen genoeg vir die gesin en dalk meer as die gesin se behoeftes. Die kos word gedeel sodat almal in staat gestel word om van mekaar se disse te kan geniet. Ongelukkig word dit nie genoeg beklemtoon dat daar 'n soort eenheid tussen die Nagmaal en die saameet is nie. Dit gebeur selde dat twee of meer gemeentes saam Nagmaal vier en dat saam aan 'n soort liefdesmaaltyd deelneem. Wanneer die etes en die uitdeel van wat oor is, plaasvind terwyl twee gemeentes uit verskillende ekonomiese omstandighede saam Nagmaal gevier het, kan persoonlike verhoudinge ontstaan en groei.

Individuele gemeentes behoort ernstige aandag te gee aan die bewustelike verbinding tussen Nagmaal en die gesamentlike ete van die gemeente vóór die diens en/of daarna. Hulle kan selfs meer voedsel of ander 


\section{Die Nagmaal en broodgebrek}

kruideniersware bring om dit na so 'n ete bewustelik te gaan uitdeel aan bepaalde mense wat broodgebrek het. De behoeftiges en hulle behoeftes kan vooraf, na raadpleging, bepaal word. Daar behoort ook soms geleenthede geskep te word waar gemeentes uit verskillende leefwêrelde hierdie handelinge saam kan uitvoer.

\subsubsection{Koppel die Nagmaalsviering en die afdra van liefdesgawes}

Die koppeling van die afdra van die liefdegawes aan die Nagmaal (direk daarna of tydens die viering) het teologies 'n radikaal ander betekenis as die gebruik in sommige gemeentes om 'n houer by die ingang van die kerkgebou te plaas waarin items vir hongeriges geplaas kan word. Laasgenoemde het meer die karakter van liefdadigheid (en in sigself nie waardeloos nie), as 'n ware liturgiese simboliese handeling (Wepener \& Cilliers 2004:370). Die wyse van die afdra van die liefdegawe as reaksie op die viering van die Nagmaal is nie onbelangrik nie. Die gebruik om die liefdegawes na die tafel te bring kom in verskeie swart kerke voor tydens die viering van die Nagmaal.

Die gebruik om die liefdegawe in die banke af te dra sou afgewissel kon word deur dit na die tafel te bring (al sou almal nie aansit nie). Die liefdegawe by so 'n geleentheid hoef nie net 'n geldelike bydrae te wees nie, maar kan selfs (soos in die Vroeë Kerk) in natura as voedsel afgedra word. Die viering en die afdra van liefdegawes (op welke manier ookal) moet as liturgiese handelinge opeenvolgend wees en die verband daartussen moet duidelik aangedui word.

\subsubsection{Laat lidmate 'n aanskoulike belewing van nood ervaar}

Een van die moontlikhede om 'n sigbare koppeling te maak tussen die Nagmaal en die afgee van die liefdegawe word deur Wepener (2003:93) aangedui as die sogenaamde hongerdoek. 'n Hongerdoek is 'n redelik algemene verskynsel in kerke wêreldwyd en behels 'n doek of bord waaraan lidmate beskrywings van honger nood uit koerante en ander inligtingsbronne voor of tydens die erediens kan vasmaak. Binne die liturgiese ruimte kan so iets 'n beeld gee van die konteks waarin baie mense lewe. So kan verbande tussen die daaglikse realiteit van die samelewing en dit wat in die liturgie gebeur op visuele wyse getrek word (Wepener \& Cilliers 2004:371). Oorhoofse projeksie (wat in verskeie gemeentes bestaan) kan ook doeltreffend voor die votum en groetseën, of as hulpmiddel vir liturgiese handelinge aangewend word. 
Gemeentes moet kreatief dink hoe verhale van hongeriges en uitbeelding daarvan sonder sensasie, maar met deernis, aan lidmate 'n beeld kan gee van 'n werklikheid waarmee hulle nie elke dag gekonfronteer word nie.

\subsubsection{Dra by om menswaardigheid te herstel}

Dit is belangrik dat kerke sal waak daarteen dat die uitwerking van die Nagmaal nie net sal wees om finansiële hulp te gee of om 'n soort liefdadigheidswerk te verrig nie, maar dat dit ook kan lei tot wesentlike liefdesbande tussen wie het en wie nie het nie. Die persoon wat broodgebrek het se grootste behoefte is dat ander hom/haar sal ken as ' $n$ mens met ' $n$ naam, met integriteit en waardigheid en nie net as nog een wat deel word van die statistiek van mense wat onder die broodlyn lewe nie. Die nuutgevormde verhoudinge moet meehelp dat daar 'n geestelike transformasie by die hongeriges kan plaasvind, wat bydra om hulle menswaardigheid te herstel.

Lidmate moet bewus gemaak word dat hulle verantwoordelikheid nie afgehandel is wanneer hulle fisies bydra om voedsel aan die hongeriges te gee nie, maar dat die fokus moet val op persoonlike verhoudinge wat bydra om die pyn van 'n minderwaardigheidsgevoel te verlig.

\subsubsection{Bied pastorale hulp aan hongeriges}

Die kerk kan maklik vergeet dat honger mense veral emosionele en psigologiese nood het en daarin ondersteun moet word. In Suid Afrika het die getal selfmoordgevalle en poging tot selfmoord drasties gestyg onder arm en honger persone. Depressie en ander verwante psigologiese siektes is geensins beperk tot die rykes nie (Du Toit 1997:291).

Kerke behoort ' $n$ unieke liefdesdiens te lewer om verligting van honger uit te brei deur pastorale hulp en ondersteuning te bied aan mense in die greep van honger.

\subsubsection{Staan ampsdraers en lidmate in honger gemeenskappe by}

Die verantwoordelikheid wat predikante, ampsdraers en lidmate het in gemeenskappe waar broodgebrek is, is te groot om alleen te kan hanteer. Gesprek met, wisseling van gedagtes en raadpleging onderling is nodig om die omvattende vraagstuk van honger aan te spreek.

Kerke wat lewe en werk in gemeenskappe waar ernstige broodgebrek is, moet bygestaan word om die krisis in hulle gemeenskappe te kan hanteer.

Die gesprekke kan veral gaan oor hoe die liturgie, wat die hele persoon insluit, 


\section{Die Nagmaal en broodgebrek}

sy/haar spiritualiteit, emosionaliteit en fisiese nood, deur gebed, liedere, belydenis, versterking deur die Woord en die Nagmaal, ingespan kan word om die honger krisis te kan hanteer en hoe hulle vanuit die vars perspektief van die liturgie hulle nood kan herformuleer.

\section{Literatuurverwysings}

Anon 2003. Africa hunger facts. Bread for the world: 2002 \& 2003 Annual Reports. Anon 2005. Famine early warning systems network. Southern Africa food security brief. August/September, 1-7.

Atkerson, S 2005. The Lord's Supper: Feast or famine. Restoring New Testament practices to today's church. http://www.ntrf.org/supper.html.

Blue, B B 1991. The house church at Corinth and the Lord's Supper: Famine, food supply, and the present distress. Chriswell Theological Review, 5(2), 221239.

Brienen, T 1987. De liturgie bij Johannes Calvijn: Zijn publicaties en zijn visies. Kampen: De Groot Goudriaan.

Boendemaker, J 1998. Maaltijd van de Heer: oecumenisch-protestant, in Oskamp, P \& Schuman, N (reds), De weg van de liturgie: Tradities, achtergronden, praktijk, 226-244. Zoetemeer: Meinema.

Calvyn, J 1991. Institusie van die Christelike godsdiens, deel 4, vertaal deur H W Simpson. Potchefstroom: CJBF.

De Klerk, B J 1987. Die Heilige Gees in die verhouding Skriflesing, prediking en gebed in die erediens. Ph D-proefskrif, Potchefstroomse Universiteit vir $\mathrm{CHO}$.

De Waal, A \& Whiteside, A 2003, New variant famine: AIDS and food crisis in Southern Africa. The Lancet 362 (9391), 1234-1237.

Du Toit, C W 1997. Empowerment of the poor: Changing our minds on affluence and poverty. Missionalia 25(3), 285-307.

Gebre-Medhin, M 2005. Gender, poverty and famines, in Hallencreutz, K (ed), Gender, poverty and church involvement, 25-33. A report from a research conference in Uppsala, May 6-8, 2002. Missio 20, Swedish Institute of Mission Research.

Gerhard, R 1993. “... und das Fest mit uns feierst”: Tendenzen gegenwärtiger Abendmahlstheologie und frommigkeit, im Spiegel neuerer Eucharistiegebete, in Cornehl, P, Dutzmann, M \& Strauch, A (Hrsg), In der Schar derer die da feiern: Feste als Gegenstand praktischer Reflexion, 180193. Göttingen: Vandenhoeck \& Ruprecht.

Gerrish, B A 1993. Grace and gratitude: The eucharistic theology of John Calvin. Minneapolis, MN: Fortress.

Havnevik, K 2005. Sub-Sahara Africa, the World Bank and poverty, in Hallencreutz, $\mathrm{K}$ (ed), Gender, poverty and church involvement, 101-112. A report from a research conference in Uppsala, May 6-8, 2002. Missio 20, Swedish Institute of Mission Research.

Leedy, P D \& Ormrod, J E 2001. Practical research: Planning and design. New Jersey, NJ: Prentice Hall. 
Leithart, P J 2000. Blessed are the hungry: Meditations on the Lord's Supper. Moscow: Canon.

Leshomo, K 2006. Communications officer for the United Nations Children's Fund (UNICEF) in an interview with IRIN in Johannesburg, April, 2006.

Leuschner, F W 2005. Atmosfeer in die erediens. Ph D-proefskrif, Potchefstroomse Universiteit vir $\mathrm{CHO}$.

Lukken, G 1996. Inculturatie van de liturgie: Theorie en praktijk, in Lamberts, J (red), Liturgie en inculturatie, 15-56. Amersfoort: Acco Leuven.

Martin, D B 1995. The Corinthian body. London: Yale University Press.

Merriam, S B 1998. Qualitative research and case study applications in education. San Francisco, CA: Jossey-Bass.

Mitchell, N D 2000. The amen corner: The rest in commentary. Worship 74(3), 248256.

Old, H O 2002. Worship: Reformed according to Scripture. Louisville, KY:

Westminister John Knox.

Oskamp, P 1998. Gebeden en gaven, in Oskamp, P \& Schuman, N, De weg van de Liturgie: Tradities, achtergronden, praktijk, 217-225. Zoetemeer: Meinema.

Phillips, D 2003. The Lord's Supper: An overview, in Ryken, P G, Thomas, D W H \& Duncan III J L (eds), Give praize to God. Phillipsburg: P \& R.

Quast, K 1994. Reading the Corinthian correspondence. New York: Paulist.

Scheer, T 1996. Ziende de Onaanzienlijke: Interpretatie van een theorie over de liturgie. Tijdschrift voor Liturgie 122-148.

Smit, D J 2004. Oor die kerk en maatskaplike uitdagings in ons land. NGTT 45(2), 350-362. (Suppl.)

Taljaard, A 2004. Die Nagmaal as middelruimte tussen ryk en arm gelowiges om sigbaarheid aan versoening in die samelewing te gee. NGTT 45(2), 373-379. (Suppl.)

Trimp, C 1989. Die gemeente en haar liturgie. Kampen: Uitgeverij Van den Berg.

UNICEF 2005. Childhood under tread: The state of the world's children. New York: Unicef house.

Uytenbogaardt, H 2002. Breek ons, Heer, het brood: Eucharistie en de SoW-kerken, in Barnard, M \& Schuman, N, Niewe wegen in de liturgie: De weg van de liturgie - een vervolg. Zoetemeer: Meinema.

Vermaak, S P J 2000. Die gemeenskaplike maaltyd in Handelinge 2:42: 'n Sosiohistoriese en Openbarings-historiese perspektief. MA-skripsie, Potchefstroomse Universiteit vir $\mathrm{CHO}$.

Versteeg, J P 1980. Het Avondmaal volgens het Nieuwe Testament, in Van't Spyker, W, Balke, W, Exalto, K \& Van Driel, L (reds), Bij brood en beker. Kampen: Goudriaan De Groot.

Vos, C J A \& Pieterse, H J C 1997. Hoe lieflik is U woning. Pretoria: RGN.

Wepener, C 2003. Basisliturgie vir Lydenstyd 2004, in Heyns, M H (reds), Reekstudies met liturgiese voorstelle gebaseer op die lesrooster. Stellenbosch: BUVTON.

Wepener, C \& Cilliers, J 2004. "In herinnering aan die kinders ... wat aan honger en koue moet sterf." Liturgie in 'n konteks van armoede. NGTT 45(2) 364-372. (Suppl.) 


\section{Die Nagmaal en broodgebrek}

Witherington, B 1995. Conflict and community in Corinth: A socio-rhetorical commentary on 1 and 2 Corinthians. Grand Rapids, MI: Eerdmans.

Zerfass, R 1974. "Praktische Teologie als Handelungswissenschaft", in Praktische Teologie heute, 164-177, edited by F Klostermann \& R Zerfass. München: Kaiser. 